\title{
KATA MAJEMUK PADA JARGON SNEAKERS BERBAHASA INGGRIS DALAM KOMUNITAS SNEAKERHEAD IST (INDONESIA SNEAKERS TEAM) BANDUNG
}

\author{
Syifa Wasilatul Fauziyah, Sugeng Riyanto, dan Agus Nero Sofyan \\ Fakultas Ilmu Budaya Universitas Padjadjaran \\ Email: Syifawasilatulfuziyah_unpad@yahoo.com;
}

\begin{abstract}
ABSTRAK. Penelitian ini bertujuan untuk mengetahui bentuk dan kategori compounding pada jargon sneakers berbahasa Inggris dalam komunitas sneakerhead IST (Indonesia Sneaker Team) Bandung. Penelitian ini dilakukan dengan menggunakan metode kualitatifdeskriptif. Data dalam penelitian ini diperoleh dengan cara mewawancarai ketua dan anggota komunitas sneakerhead IST (Indonesia Sneaker Team) Bandung. Hasil dalam penelitian ini menunjukkan bahwa proses compounding dalam jargon sneakers berbahasa Inggris dalam komunitas sneakerhead IST (Indonesia Sneaker Team) Bandung, dapat diklasifikasikan pada dua bentuk yang terdiri daro bentuk tulisan dan bentuk kata majemuk. Berdasarkan bentuk tulisan didapati dua bentuk tulisan yaitu close form (bentuk tertup) dan open form (bentuk terbuka), kemudian berdasarkan bentuk kata mejemuknya didapati dua bentuk, yaitu berbentuk endocentic compound dan excocentric compound. Kategori kata dalam jargon sneakers berbahasa Inggris dalam komunitas sneakerhead IST Bandung didapati kategori compound nomina yang dapat diklasifikasikan pada tiga bentuk compound nomina, yaitu compound nomina (nomina+nomina), compound nomina (nomina+verba), dan compound nomina (adjectiva + nomina/nomina + adjektiva).
\end{abstract}

Kata kunci: morfologi; compounding; jargon.

\section{COMPOUNDING ON ENGLISH SNEAKERS JARGON IN IST SNEAKERHEAD COMMUNITY (INDONESIA SNEAKERS TEAM) BANDUNG}

\begin{abstract}
This research aims to describe the compounding form and category of English sneakers jargon in the IST (Indonesian Sneaker Team) sneakerhead community in Bandung. The method in this research is used qualitative descriptive research method. The data in this research were obtined by interviewing the head and the members of IST (Indonesia Sneaker Team) Bandung. The result of this research shows that the compounding process in the English sneakers jargon in IST (Indonesian Sneaker Team) Bandung can be classified into two forms they are writing forms and compounding forms. In writing forms they are open form and close forms and the form of compounding they are endocentric compound and exocentric compound. The category of the data they are compound noun which can be divided into three categories of compound nouns, they are compound nouns (noun + noun), compound noun (noun+verb), and compound noun (adjective + noun / noun + adjective).
\end{abstract}

Key words: morfologi; compounding; jargon.

\section{PENDAHULUAN}

Bahasa merupakan sistem lambang bunyi arbiter yang digunakan untuk berkomunikasi oleh masyarakat pemakainya. Bahasa sebagai sarana dalam berkomunikasi berfungsi untuk menyampaikan pesan, pikiran, ide, gagasan, dan perasaan. Bahasa merupakan alat identifikasi bagi masyarakat pemakainya. Satu di antara wujud bahasa sebagai alat identifikasi adalah adanya istilah-istilah khusus yang digunakan dalam kelompok-kelompok tertentu. Setiap disiplin ilmu, profesi, bidang atau komunitas tertentu memiliki istilah-istilah khusus yang menjadi ciri khas bidang tersebut. Istilah-istilah itu disebut sebagai jargon, yaitu sejumlah kata atau istilah khusus yang diciptakan oleh kelompok tertentu dan merujuk pada suatu bidang atau keahlian kelompok itu. Satu di antara contohnya adalah jargon-jargon yang ada dalam komunitas pecinta sneakers. Jargon-jargon sneakers digunakan untuk menjelaskan tipe, kondisi, bentuk, bagian, atau sejarah sebuah sneakers. Menurut Longman (2000: 405) "Sneakers adalah light shoe worn for sport'. Sepatu ringan yang digunakan untuk berolah raga. Sneakers merupakan sepatu ringan yang terbuat dari sol karet. Sejarahnya, sneakers berasal dari kata sneak yang berarti mengendap-endap, sehingga saat digunakan sepatu sneakers itu tidak akan mengeluarkan suara, berbeda halnya dengan sepatu boots atau heels.

Sneakers tidak hanya menjadi pelindung alas kaki, kini sneakers menjadi sebuah trend fashion yang kerap digemari oleh masyarakat dan merambah berbagai kalangan sehingga dari tahun ke tahun pecinta sneakers atau yang disebut para sneakerhead kian bertambah dan melonjak. Menurut Smith (2018: 233-235), sneakerhead merupakan individu yang memiliki berbagai sneakers dengan berbagai merek/brand dan berbasis memiliki pengetahuan seputar sneakers. Mereka merupakan pengikut kebudayaan atau trend terutama dalam penggunaan dan pemakaian sepatu sneakers. Sebagai komunitas pecinta sepatu sneakers, para sneakerhead memiliki istilah-istilah khusus, yaitu jargon-jargon yang ada dalam komunitas itu. Banyaknya jargon sneakers berbahasa Inggris dengan pembentukan kata-kata dan memiliki makna yang unik menarik untuk diteliti. Satu di antara contohnya adalah jargon- 
jargon sneakers yang berbentuk compounding (kata majemuk). Jargon sneakers yang berbentuk compounding menarik untuk diteliti karena proses compounding merupakan proses yang menyatukan dua morfem bebas menjadi satu istilah baru dan memiliki makna baru.

Penelitian ini terinspirasi oleh penelitian terdahulu, yaitu "Blending: Sebuah Alternatif dalam Penamaan Makanan dan Minuman Ringan” yang ditulis oleh Giyatmi Giyatmi, dkk. pada tahun 2018 yang meneliti tentang jenis serta bentuk blending dalam penamaan makanan dan minuman ringan, "Penggunaan Jargon oleh Narapidana di Lapas Wanita Kelas IIA Medan" yang ditulis oleh Dini Wahyuni pada tahun 2015 yang meneliti tentang proses pembentukan kata pada jargon-jargon narapidana di Lapas Medan. Selanjutntya, "Penggunaan Jargon oleh Komunitas Waria di Jejaring Sosial Facebook" yang ditulis oleh Jusmiati Garing tahun 2017 yang meneliti tentang bentuk-bentuk jargon yang digunakan oleh komunitas waria di jejaring sosial dan jenis semantik serta perubahan yang ada pada jargon tersebut. Dalam penelitian ini difokuskan untuk mendeskripsikan proses pembentukan compounding dalam jargon sneakers berbahasa Inggris dalam komunitas sneakerhead IST Bandung. Penelitian ini merupakan penelitian kajian bidang morfologi.

Morfologi merupakan bidang linguistik yang mempelajari tentang morfem dan kombinasi-kombinasinya atau bagian dari struktur bahasa yang mencakup kata dan bagian dari kata-kata itu yaitu morfem (Kridalaksana, 2008: 159). Senada dengan hal itu, Booij (2005: 24) berpendapat bahwa morfologi merupakan bidang linguistik yang mempelajari struktur internal kata-kata, berhubungan dengan bentuk-bentuk kata, dan proses pembentukan kata. Lebih lanjut, O'Grady dan Archibald (2009: 100) mengemukakan bahwa morfologi merupakan bagian dari tata bahasa yang mengkaji tentang kata dan pembentukan kata dalam sebuah kalimat. Dari ketiga definisi itu, dapat disimpulkan bahwa morfologi merupakan bidang linguistik yang mengkaji tentang kata yaitu struktur internal kata, bentuk kata, dan proses bagaimana kata itu terbentuk (proses pembentukan kata). Adapun proses pembenukan kata yang akan dikaji dalam penelitian ini satu di antaranya adalah proses compounding pada jargon sneakers berbahasa Inggris dalam komunitas sneakerhead IST Bandung. Yule (2016: 55) berpendapat bahwa compounding atau yang dalam bahasa Indonesia disebu sebagai kata majemuk, merupakan gabungan dari dua kata yang berbeda untuk membentuk kata baru. Senada dengan hal itu, Lieber (2007: 43) menyatakan bahwa kata majemuk merupakan kata yang dibentuk dari dua (atau lebih) bentuk morfem dasar. Compounding atau yang dalam bahasa Indonesia disebut sebagai kata majemuk merupakan proses penggabungan dua morfem atau lebih untuk membentuk sebuah kata baru. Ciri-ciri kata majemuk dalam bahasa Inggris dapat disimpulkan sebagai berikut.

a. Kata majemuk dalam bahasa Inggris terdiri dari tiga bentuk tulisan, yaitu close form (bentuk tertutup), open form (bentuk terbuka), dan hypnated form (bentuk penghubung). Katamba, dkk. dalam Cahyanti (2016: 61) berpendapat bahwa kata majemuk memiliki tiga bentuk yang pertama adalah kata majemuk bentuk tertutup (close form) yaitu kata majemuk yang ditulis sebagai kata tunggal (newspaper, highway, goldfish), yang kedua kata majemuk hyphenated form, yaitu kata majemuk yang ditulis dengan tanda penghubung (mother-in-law, second-rate), dan yang terakhir adalah kata majemuk yang berbentuk terbuka (open form) yaitu kata majemuk yang ditulis sebagai kata-kata terpisah (high school, health care).

b. Kata majemuk dalam bahasa Inggris terdiri dari kombinasi kategori leksikal (nomina, verba, adjektiva, dan adverbia). O'Grady dan Dobrovolsky dalam Cahyanti (2016: 66) berpendapat bahwa dalam bahasa Inggris kata majemuk merupakan kombinasi dari kategori leksikal (nomina, verba, adjektiva, dan preposisi) dan morfem yang paling kanan disebut sebagai inti kata (head) karena morfem tersebut akan menentukan kategori dari kata majemuk itu. Misalnya, bookstore (nomina), break dance (verba), red hot (adjektiva).

c. Kata majemuk dalam bahasa Inggris dapat dikenali pada pola pengucapan morfem pertama. Jackson dalam Napitupulu (2016: 7) mengemukakan bahwa dalam bahasa Inggris beberapa kata majemuk dikenali oleh pola pengucapan pada morfem pertama, contohnya 'blackbird (kata majemuk) 'blackbird' (frasa), 'black board (kata majemuk), 'blackboard' (frasa).

d. Kata majemuk dalam bahasa Inggris dapat dibedakan menjadi tiga bentuk, yaitu endocentric compound, exocentric compound dan copulative compound. Plag (2002: 186-188) menjelaskan bahwa dalam bahasa Inggris terdapat endocentric compound, exocentric compound, dan copulative compounds. Endocentric compound merupakan kata majemuk yang maknanya ditentukan oleh the head of compound words inti kata dari sebuah kata majemuk, contohnya laser printer merupakan sebuah printer dan book cover merupakan sebuah cover. Kemudian, exocentric compound merupakan makna kata majemuk yang tidak dapat diprediksi dari inti kata majemuk yang ada, artinya makna exocentric compounds merupakan makna yang benar-benar baru. Misalnya, kata redneck bukan merupakan sebuah leher tapi mengacu pada orang-orang yang berkulit putih yang tinggal di pedesaan yaitu di wlayah selatan Amerika serikat, 
biasanya redneck digunakan sebagai kata penghinaan, loudmouth bukan merupakan sejenis mulut tetapi mengacu kepada seorang pembual besar, dengan demikian makna exocentric merupakan sebuah makna yang baru yang tidak mempertahankan makna aslinya (Plag, 2002: 186). Copulative compound merupakan makna kata majemuk yang maknanya diambil dari dua inti kata majemuk itu. Misalnya, kata poet-translator merupakan seorang penyair dan seorang penerjemah, kata singer-songwriter merupakan seorang penyanyi dan penulis lagu (Plag, 2002: 188).

\section{METODE}

Penelitian ini menggunakan metode deskriptif kualitatif. Menurut Surakahmad dalam Firdaus (2011: 225) "Metode deskriptif merupakan sebuah metode penelitian yang dalam pelaksanaannya tidak terbatas hanya sampai pengumpulan data saja, melainkan meliputi analisis dan interpretasi tentang arti data". Metode itu bertujuan untuk mendeskripsikan bentuk compounding pada jargon sneakers dalam komunitas sneakerhead IST Bandung. Selanjutnya, data dikumpulkan dengan menggunakan teknik simak libat cakap dan teknik catat. Metode simak libat cakap menurut Sudaryanto (2015: 203) merupakan metode pengumpulan data dimana peneliti menyimak dan terlibat dalam wawancara ketika pengambilan data. Adapun nama ketua dan anggota komunitas sneakerhead IST Bandung yakni:
a. Rinaldy Muharram
b. Firman Yousaf
c. Handiva Putra
d. Raka Pawita
e. Rizky Ariansyah

Wawancara dengan ketua dan anggota komunitas itu dilakukan pada tanggal 2 Februari 2019. Metode analisis yang digunakan dalam penelitian ini yaitu metode agih dengan teknik dasar teknik BUL dan metode padan referensial. Metode agih merupakan cara menganalisis data yang alat penelitiannya berada dalam bahasa yang bersangkutan itu sendiri (Sudaryanto, 2015: 18). Teknik yang dipilih adalah teknik dasar yaitu teknik BUL. Menurut Sudaryanto (2015: 37) teknik bagi unsur langsung atau teknik BUL merupakan teknik analisis yang digunakan untuk membagi data menjadi beberapa bagian yaitu untuk membentuk satuan lingual yang dimaksud. Berdasarkan tujuan penelitian, untuk memberikan data yang relevan, penulis menggunakan teknik bagi unsur langsung (BUL) untuk menganalisis bentuk compounding. pada jargon-jargon sneakers berbahasa Inggris yang ada dalam komunitas sneakerhead IST Bandung. Untuk tujuan selanjutnya adalah mendeskripsikan makna jargon sneakers, penulis menggunakan metode padan referensial dengan menggunakan teknik dasar teknik pilah unsur penentu. Sudaryanto (2015: 15) berpendapat bahwa metode padan merupakan metode analisis yang alat penelitiannya berada diluar bahasa yang bersangkutan itu sendiri. Penelitian ini menggunakan metode padan referensial dengan menggunakan alat penentu referen untuk menganalisis makna pada jargon sneakers berbahasa Inggris. Sudaryanto (2015: 15) berpendapat bahwa metode padan referensial merupakan metode yang alat penentunya merupakan kenyataannya/referen yang ditunjuk oleh bahasa.

\section{HASIL DAN PEMBAHASAN}

Paparan dalam penelitian ini disusun berdasarkan bentuk dan kategori kata majemuk. Secara bentuk dapat dibedakan dari bentuk penulisan dan bentuk kata majemuk. Bentuk penulisan kata majemuk terdiri dari open form, yaitu kata majemuk yang ditulis sebagai kata tunggal dan close form, yaitu kata majemuk yang ditulis sebagai kata terpisah, kemudian bentuk kata majemuk pada jargon sneakers berbahasa Inggris, dapa dibendakan menjadi bentuk endocentric compound dan exocentric compound. Berikut ini adalah pemparan analisis bentuk tulisan, bentuk kata majemuk, dan kategori kata pada jargon sneakers berbahasa Inggris dalam komunitas sneakerhead IST Bandung.

\section{Compound nomina (nomina + nomina) \\ Data 1: Shelltoe}

Pengkajian secara morfologis pada jargon shelltoe menunjukkan bagian dari proses morfologis yang disebut compounding atau dalam bahasa Indonesia disebut kata mejemuk. Proses compounding pada jargon shelltoe dibentuk dengan cara menggabungkan dua morfem bebas, yaitu morfem shell dan morfem toe. Jargon shelltoe merupakan kata majemuk yang ditulis dengan bentuk close form (bentuk tertutup) karena jargon shelltoe ditulis sebagai kata tunggal. Jargon shelltoe merupakan bentuk dari endocentric compound, karena memiliki satu inti kata (head) untuk mengetahui makna yang ada. Adapun inti kata pada jargon itu, terletak pada kata toe, karena shelltoe merupakan bagian depan dari sneakers Adidas yang menyerupai bentuk kerang dan menutupi jari kaki. Berdasarkan kategorinya, jargon shelltoe merupakan sebuah compound nomina karena terbentuk dari morfem shell berkategori nomina dan morfem toe yang juga berkategori nomina.

\section{Data 2: Eye Stay}

Pengkajian secara morfologis pada jargon eye stay menunjukkan bagian proses morfologis yang disebut 
compounding atau dalam bahasa Indonesia disebut kata majemuk. Proses compounding pada jargon eye stay dibentuk dengan cara menggabungkan dua morfem bebas, yaitu morfem eye dan morfem stay. Jargon eye stay merupakan kata majemuk yang ditulis dengan bentuk open form (bentuk terbuka) karena jargon eye stay ditulis secara terpisah.Jargon eye stay merupakan bentuk dari exocentric compound, karena tidak memiliki inti kata (head) untuk mengetahui makna yang ada, , eye stay merupakan lubang tali sneakers yang berbentuk bulat yang menjadi bagian dari sepatu sneakers. Berdasarkan kategorinya, jargon eye stay merupakan sebuah compound nomina karena terbentuk dari morfem eye yang berkategori nomina dan morfem stay yang juga berkategori nomina.

\section{Data 3: Colorway}

Pengkajian secara morfologis pada jargon colorway menunjukkan bagian proses morfologis yang disebut compounding atau dalam bahasa Indonesia disebut kata majemuk. Proses compounding pada jargon colorway dibentuk dengan cara menggabungkan dua morfem bebas, yaitu morfem color dan morfem way. Jargon colorway merupakan kata majemuk yang ditulis dengan bentuk close form (bentuk tertutup) karena jargon colorway ditulis sebagai kata tunggal. Jargon colorway merupakan bentuk kata majemuk endocentric compound, karena memiliki satu inti kata (head) untuk mengetahui makna yang ada. Adapun inti kata itu terletak pada kata color, karena colorway merupakan kombinasi warna yang ada dalam sneakers, misalnya sneakers dengan colorway bred yaitu kombinasi black and red.

Berdasarkan kategorinya, jargon colorway merupakan sebuah compound nomina karena terbentuk dari morfem color yang berkategori nomina dan morfem way yang juga berkategori nomina.

\section{Data 4: Sneakerhead}

Pengkajian secara morfologis pada jargon sneaker head menunjukkan bagian proses morfologis yang disebut compounding atau dalam bahasa Indonesia disebut kata majemuk. Proses compounding pada jargon sneakerhead dibentuk dengan cara menggabungkan dua morfem bebas, yaitu morfem sneaker dan morfem head. Jargon sneakerhead merupakan kata majemuk yang ditulis dengan bentuk close form (bentuk tertutup) karena jargon sneakerhead ditulis sebagai kata tunggal. Jargon sneakerhead merupakan bentuk kata majemuk endocentric compound, karena memiliki satu inti kata (head) untuk mengetahui makna yang ada. Adapun inti kata itu terletak pada kata sneaker, karena sneakerhead merupakan orang-orang yang mencintai sepatu sneakers, memiliki berbagai merek atau jenis sneakers, dan berbasis memiliki pengetahuan seputar sneakers, biasanya orang- orang itu membentuk sebuah komunitas pecinta sepatu sneakers, yang kemudian terbentuk komunitas sneakerhead yang ada.Berdasarkan kategorinya, jargon sneakerhead merupakan sebuah compound nomina karena terbentuk dari morfem sneaker yang berkategori nomina dan morfem head yang juga berkategori nomina.

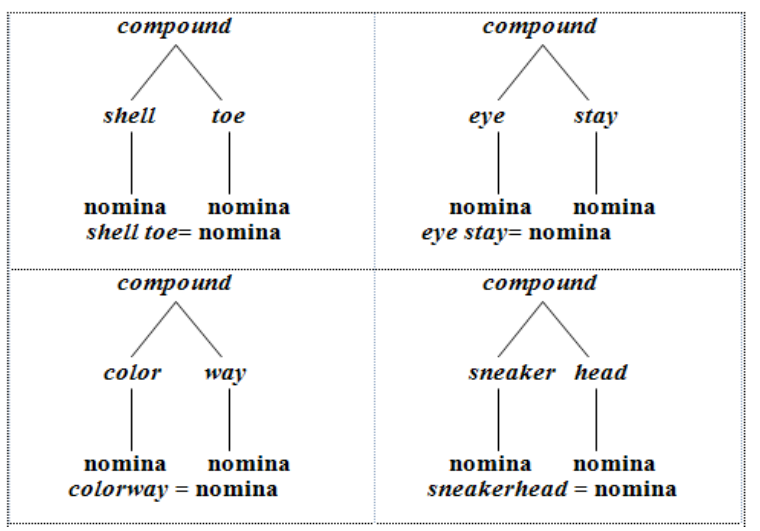

Gambar 1. proses pembentukan jargon compounding shelltoe, eye stay, colorway, dan snekarhead

\section{Data 5: Gum Sole}

Pengkajian secara morfologis pada jargon gum sole menunjukkan bagian proses morfologis yang disebut compounding atau dalam bahasa Indonesia disebut kata majemuk. Proses compounding pada jargon gum sole dibentuk dengan cara menggabungkan dua morfem bebas, yaitu morfem gum dan morfem sole. Jargon gum sole merupakan kata majemuk yang ditulis dengan bentuk open form (bentuk terbuka) karena jargon gum sole ditulis sebagai kata yang terpisah. Jargon gum sole merupakan bentuk kata majemuk endocentric compound, karena memiliki satu inti kata (head) untuk mengetahui makna yang ada. Adapun inti kata itu terletak pada kata sole, karena gum sole merupakan sole sepatu sneakers yang berwarna kuning kecoklatan mirip dengan permen karet. Berdasarkan kategorinya, jargon gum sole merupakan sebuah compound nomina karena terbentuk dari morfem gum yang berkategori nomina dan morfem sole yang juga berkategori nomina.

\section{Data 6: Player Edition}

Pengkajian secara morfologis pada jargon player edition menunjukkan bagian dari proses morfologis yang disebut compounding atau dalam bahasa Indonesia disebut kata mejemuk. Proses compounding pada jargon player edition dibentuk dengan cara menggabungkan dua morfem bebas, yaitu morfem player dan morfem edition. Jargon player edition merupakan kata majemuk yang ditulis dengan bentuk open form (bentuk terbuka) karena jargon player edition ditulis sebagai kata yang terpisah. Jargon player edition merupakan bentuk dari endocentric compound, karena memiliki satu inti kata (head) untuk mengetahui makna yang ada. Adapun inti kata itu terletak 
pada kata player, karena player edition merupakan sejenis sneakers yang di rancang sesuai keinginan atlet tertentu yang kemudian sneakers itu akan di rilis secara umum, contohnya seperti sneakers Adidas stan smith dan sneakers Nike Jordan. Berdasarkan kategorinya, jargon player edition merupakan sebuah compound nomina karena terbentuk dari morfem player berkategori nomina dan morfem edition yang berkategori nomina.

\section{Data 7: Salmon Sole}

Pengkajian secara morfologis pada jargon salmon sole menunjukkan bagian dari proses morfologis yang disebut compounding atau dalam bahasa Indonesia disebut kata mejemuk. Proses compounding pada jargon salmon sole dibentuk dengan cara menggabungkan dua morfem bebas, yaitu morfem salmon dan morfem sole. Jargon salmon sole merupakan kata majemuk yang ditulis dengan bentuk open form (bentuk terbuka) karena jargon salmon sole ditulis sebagai kata yang terpisah. Jargon salmon sole merupakan bentuk dari endocentric compound, karena memiliki satu inti kata (head) untuk mengetahui makna yang ada. Adapun inti kata itu terletak pada kata sole, karena salmon sole merupakan sol yang ada pada sneakers New Balance, yaitu warna sol yang berwarna pink agak kekuningan, mirip warna daging ikan salmon. Berdasarkan kategorinya, jargon salmon sole merupakan sebuah compound nomina karena terbentuk dari morfem salmon berkategori nomina dan morfem sole yang berkategori nomina.

\section{Data 8: Grade School}

Pengkajian secara morfologis pada jargon grade school menunjukkan bagian dari proses morfologis yang disebut compounding atau dalam bahasa Indonesia disebut kata mejemuk. Proses compounding pada jargon grade school dibentuk dengan cara menggabungkan dua morfem bebas, yaitu morfem grade dan morfem school. Jargon grade school merupakan kata majemuk yang ditulis dengan bentuk open form (bentuk terbuka) karena jargon grade school ditulis sebagai kata yang terpisah. Jargon grade school merupakan bentuk dari endocentric compound, karena memiliki satu inti kata (head) untuk mengetahui makna yang ada. Adapun inti kata itu terletak pada kata schooi, karena grade school merupakan sneakers yang ukurannya dikhususkan untul anak sekolah biasanya dari ukuran 36 sampai 40. Berdasarkan kategorinya, jargon grade school merupakan sebuah compound nomina karena terbentuk dari morfem grade berkategori nomina dan morfem school yang juga berkategori nomina. dapat dijalaskan pada gambar 2 .

\section{Data 9: City Series}

Pengkajian secara morfologis pada jargon city series menunjukkan bagian dari proses morfologis yang disebut

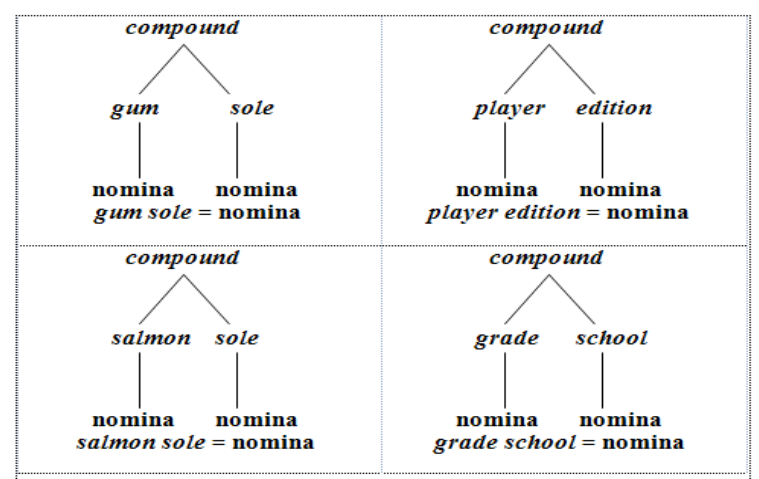

Gambar 2. proses pembentukan jargon compounding gum sole, player edition, salmon sole, dan grade school

compounding atau dalam bahasa Indonesia disebut kata majemuk. Proses compounding pada jargon city series dibentuk dengan cara menggabungkan dua morfem bebas, yaitu morfem city dan morfem series. Jargon city series merupakan kata majemuk yang ditulis dengan bentuk open form (bentuk terbuka) karena jargon city series ditulis secara terpisah. Jargon city series merupakan bentuk dari endocentric compound, karena memiliki satu inti kata (head) untuk mengetahui makna yang ada. Adapun inti kata itu terletak pada kata series, karema city series merupakan seri dari sneakers Adidas yang nama serinya diambil dari nama-nama kota di negara Eropa, contohnya seperti Adidas Brimingham dan Adidas Berlin. Berdasarkan kategorinya, jargon city series merupakan sebuah compound nomina karena terbentuk dari morfem city yang berkategori nomina dan morfem series yang berkategori nomina.

\section{Data 10: Island Series}

Pengkajian secara morfologis pada jargon island series menunjukkan bagian proses morfologis yang disebut compounding atau dalam bahasa Indonesia disebut kata majemuk. Proses compounding pada jargon island series dibentuk dengan cara menggabungkan dua morfem bebas, yaitu island dan series. Jargon island series merupakan kata majemuk yang ditulis dengan bentuk open form (bentuk terbuka) karena jargon island series ditulis secara terpisah. Jargon island series merupakan bentuk dari endocentric compound, karena memiliki satu inti kata (head) untuk mengetahui makna yang ada. Adapun inti kata itu terletak pada kata series, karena island series merupakan seri dari sneakers Adidas yang nama serinya diambil dari nama-nama pulau, contohnya seperti Adidas Java dan Adidas Borneo. Berdasarkan kategorinya, jargon island series merupakan sebuah compound nomina karena terbentuk dari morfem island yang berkategori nomina dan morfem series yang berkategori nomina.

\section{Data 11: Air Safari}

Pengkajian secara morfologis pada jargon air safari menunjukkan bagian proses morfologis yang disebut 
compounding atau dalam bahasa Indonesia disebut kata majemuk. Proses compounding pada jargon air safari dibentuk dengan cara menggabungkan dua morfem bebas, yaitu morfem air dan morfem safari. Jargon air safari merupakan kata majemuk yang ditulis dengan bentuk open form (bentuk terbuka) karena jargon air safari ditulis secara terpisah. Jargon air safari merupakan bentuk dari endocentric compound, karena memiliki satu inti kata (head) untuk mengetahui makna yang ada. Adapun inti kata itu terletak pada kata safari, karena air safari merupakan sneakers dari Nike yaitu sneakers yang memiliki sol dari bantalan udara, dirilis pada tahun 1986, beberapa bagian dari sneakers itu terbuat dari kulit ular, dirancang dengan pola macan tutul dan sneaker itu berfungsi sebagai sepatu lari. Air safari yang merupakan endocentric compound memiliki satu inti kata (head) untuk mengetahui makna yang ada. Berdasarkan kategorinya, jargon air safari merupakan sebuah compound nomina karena terbentuk dari morfem air yang berkategori nomina dan morfem safari yang berkategori nomina.

\section{Data 12: Air Woven}

Pengkajian secara morfologis pada jargon air woven menunjukkan bagian proses morfologis yang disebut compounding atau dalam bahasa Indonesia disebut kata majemuk. Proses compounding pada jargon air woven dibentuk dengan cara menggabungkan dua morfem bebas, yaitu morfem air dan morfem woven. Jargon air woven merupakan kata majemuk yang ditulis dengan bentuk open form (bentuk terbuka) karena jargon air woven ditulis secara terpisah. Jargon air woven merupakan bentuk dari endocentric compound, karena memiliki satu inti kata (head) untuk mengetahui makna yang ada. Adapun inti kata itu terletak pada kata woven, karena air woven merupakan jenis sneakers Nike yang dibuatnya dengan cara di tenun mirip bentuk tenun yang ada pada sebuah keranjang. Kemudian, sol sneakers itu terbuat dari bantalan udara. Sneakers dengan jenis air woven ini dirilis pada tahun 2000 pada awal revolusi, sneakers itu dibuat dengan menyusung tema kehidupan di pedesaan yang mata pencaharian desa itu adalah menenun. Berdasarkan kategorinya, jargon air woven merupakan sebuah compound nomina karena terbentuk dari morfem air yang berkategori nomina dan morfem woven yang berkategori nomina.

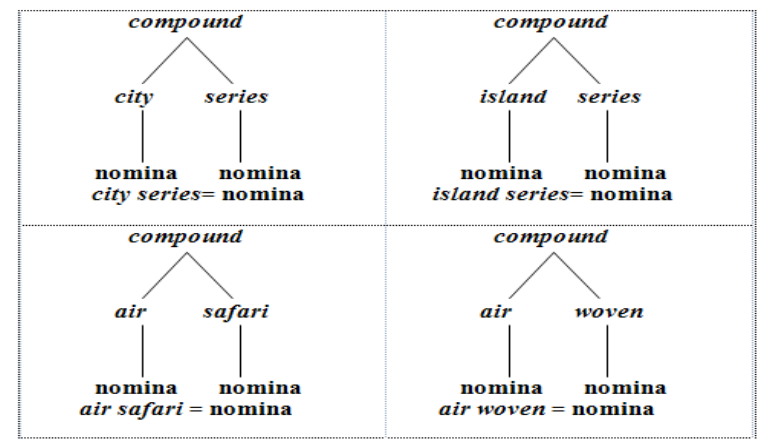

Gambar 3. proses pembentukan jargon compounding city series, island series, air safari, dan air woven:

\section{Data 13: Lava Dome}

Pengkajian secara morfologis pada jargon lava dome menunjukkan bagian dari proses morfologis yang disebut compounding atau dalam bahasa Indonesia disebut kata mejemuk. Proses compounding pada jargon lava dome dibentuk dengan cara menggabungkan dua morfem bebas, yaitu morfem lava dan morfem dome. Jargon lava dome merupakan kata majemuk yang ditulis dengan bentuk open form (bentuk terbuka) karena jargon lava dome ditulis sebagai kata yang terpisah. Jargon lava dome merupakan bentuk dari exocentric compound, karena tidak memiliki memiliki inti kata (head) untuk mengetahui makna yang ada, lava dome merupakan sneakers Nike yang dirilis pada tahun 1989, yaitu sneakers yang di rancang khusus untuk climbing mountains yaitu untuk mendaki gunung. Bahan sneakers itu di sesuaikan dengan kebutuhan dari pendaki gunung, sneakers itu merupakan sneakers yang dapat digunakan dengan fleksibel namun tetap kuat. Berdasarkan kategorinya, jargon lava dome merupakan sebuah compound nomina karena terbentuk dari morfem lava berkategori nomina dan morfem dome yang berkategori nomina.

\section{Compound nomina (nomina + verba) \\ Data 14: Size Run}

Pengkajian secara morfologis pada jargon size run menunjukkan bagian dari proses morfologis yang disebut compounding atau dalam bahasa Indonesia disebut kata mejemuk. Proses compounding pada jargon size run dibentuk dengan cara menggabungkan dua morfem bebas, yaitu morfem size dan morfem run. Jargon size run merupakan kata majemuk yang ditulis dengan bentuk open form (bentuk terbuka) karena jargon size run ditulis sebagai kata yang terpisah. Jargon size run merupakan bentuk dari endocentric compound, karena memiliki satu inti kata (head) untuk mengetahui makna yang ada. Adapun inti kata itu terletak pada kata size, karena size run merupakan ukuran sneakers yang dimiliki oleh toko tertentu, yang biasanya toko itu memiliki ukuran yang lengkap dari ukuran 6-12. Berdasarkan kategorinya, jargon size run merupakan sebuah compound nomina karena terbentuk dari morfem size berkategori nomina dan morfem run yang berkategori verba.

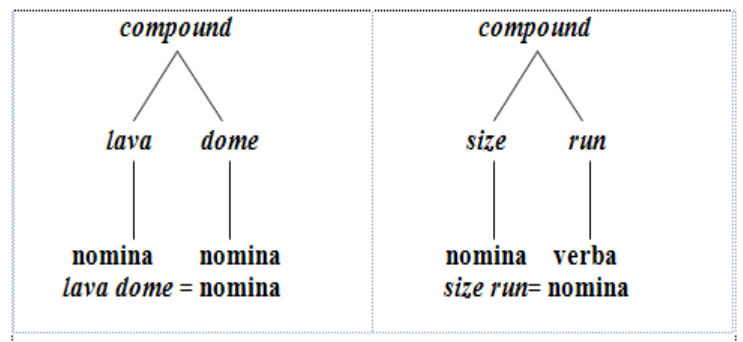

Gambar 4. proses pembentukan jargon compounding lava dome dan size run.

Kata Majemuk pada Jargon Sneakers Berbahasa Inggris dalam Komunitas Sneakerhead IST (Indonesia Sneakers Team) Bandung (Syifa Wasilatul Fauziyah, Sugeng Riyanto, dan Agus Nero Sofyan) 
Compound nomina (adjektiva + nomina/ nomina + adjektiva)

\section{Data 15 : Broken Size}

Pengkajian secara morfologis pada jargon broken size menunjukkan bagian proses morfologis yang disebut compounding atau dalam bahasa Indonesia disebut kata majemuk. Proses compounding pada jargon itu dibentuk dengan cara menggabungkan dua morfem bebas, yaitu morfem broken dan morfem size. Jargon broken size merupakan kata majemuk yang ditulis dengan bentuk open form (bentuk terbuka) karena jargon broken size ditulis secara terpisah. Jargon broken size merupakan bentuk kata majemuk endocentric compound, karena memiliki satu inti kata (head) untuk mengetahui makna yang ada. Adapun inti kata itu terletak pada kata size, karena broken size merupakan ukuran sneakers yang tidak lengkap dalam sebuah toko. Berdasarkan kategorinya, jargon broken size merupakan sebuah compound nomina karena terbentuk dari morfem broken yang berkategori adjektiva dan morfem size yang berkategori nomina.

\section{Data 16: Player Exclusive}

Pengkajian secara morfologis pada jargon player exclusive menunjukkan bagian dari proses morfologis yang disebut compounding atau dalam bahasa Indonesia disebut kata mejemuk. Proses compounding pada jargon player exclusive dibentuk dengan cara menggabungkan dua morfem bebas, yaitu morfem player dan morfem exclusive. Jargon player exclusive merupakan kata majemuk yang ditulis dengan bentuk open form (bentuk terbuka) karena jargon player exclusive ditulis sebagai kata yang terpisah. Jargon player exclusive merupakan bentuk dari endocentric compound, karena memiliki satu inti kata (head) untuk mengetahui makna yang ada. Adapun inti kata itu terletak pada kata player, karena player exclusive merupakan sneakers yang di buat khusus untuk seorang atlet tertentu dan tidak dirilis secara umum.Berdasarkan kategorinya, jargon player exclusive merupakan sebuah compound nomina karena terbentuk dari morfem player berkategori nomina dan morfem exclusive yang berkategori adjektiva.

\section{Data 17: Golden Size}

Pengkajian secara morfologis pada jargon golden size menunjukkan bagian dari proses morfologis yang disebut compounding atau dalam bahasa Indonesia disebut kata majemuk. Proses compounding pada jargon golden size dibentuk dengan cara menggabungkan dua morfem bebas, yaitu morfem golden dan morfem size. Jargon golden size merupakan kata majemuk yang ditulis dengan bentuk open form (bentuk terbuka) karena jargon golden size ditulis sebagai kata yang terpisah. Jargon golden size merupakan bentuk dari kata majemuk endocentric compound, karena memiliki satu inti kata (head) untuk mengetahui makna yang ada. Adapun inti kata itu terletak pada kata size, karena golden size merupakan ukuran sneakers yang paling banyak diminati, contohnya jika di indoneasia rata-rata ukuran yang diminati itu ukuran 42 $\mathrm{cm}$ dan $43 \mathrm{~cm}$. Berdasarkan kategorinya, jargon golden size merupakan sebuah compound nomina karena terbentuk dari morfem golden yang berkategori adjektiva dan morfem size yang berkategori nomina.

\section{Data 18: Down Size}

Pengkajian secara morfologis pada jargon down size menunjukkan bagian dari proses morfologis yang disebut compounding atau dalam bahasa Indonesia disebut kata majemuk. Proses compounding pada jargon down size dibentuk dengan cara menggabungkan dua morfem bebas, yaitu morfem down dan morfem size. Jargon down size merupakan kata majemuk yang ditulis dengan bentuk open form (bentuk terbuka) karena jargon down size ditulis sebagai kata yang terpisah. Jargon down size merupakan bentuk dari kata majemuk endocentric compound, karena memiliki satu inti kata (head) untuk mengetahui makna yang ada. Adapun inti kata itu terletak pada kata size, karena down size merupakan ukuran pada kaki seseorang yang biasanya menggunakan sneaker dengan ukuran 38 menjadi 37, jadi ukurannya turun $1 \mathrm{~cm}$. Berdasarkan kategorinya, jargon down size merupakan sebuah compound nomina karena terbentuk dari morfem down yang berkategori adjektiva dan morfem size yang berkategori nomina.

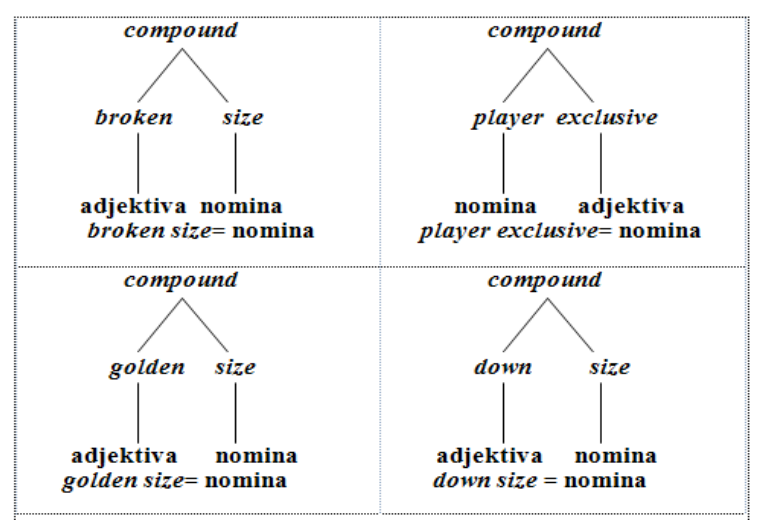

Gambar 5. proses pembentukan jargon compounding broken size, player exclusive, golden size, dan down size.

\section{Data 19: Hyperstrike}

Pengkajian secara morfologis pada jargon hyperstrike menunjukkan bagian dari proses morfologis yang disebut compounding atau dalam bahasa Indonesia disebut kata majemuk. Proses compounding pada jargon hyperstrike dibentuk dengan cara menggabungkan dua morfem bebas, yaitu morfem hyper dan morfem strike. Jargon hyperstrike merupakan kata majemuk yang ditulis dengan bentuk close form (bentuk tertutup) 
karena jargon hyperstrike ditulis sebagai kata tunggal. Jargon hyperstrike merupakan bentuk dari kata majemuk exocentric compound, karena jargon itu tidak memiliki inti kata (head) untuk mengetahui makna yang ada. Hyperstrike merupakan sebuah sneakers rilisan limited yang biasanya dirilis tanpa pemberitahuan yang tibatiba habis. Berdasarkan kategorinya, jargon hyperstrike merupakan compound nomina karena terbentuk dari morfem hyper yang berkategori adjektiva dan morfem strike yang berkategori nomina.

\section{Data 20: Super Shell}

Pengkajian secara morfologis pada jargon super shell menunjukkan bagian dari proses morfologis yang disebut compounding atau dalam bahasa Indonesia disebut kata majemuk. Proses compounding pada jargon super shell dibentuk dengan cara menggabungkan dua morfem bebas, yaitu morfem super dan morfem shell. Jargon super shell merupakan kata majemuk yang ditulis dengan bentuk open form (bentuk terbuka) karena jargon super shell ditulis sebagai kata terpisah. Jargon super shell merupakan bentuk dari kata majemuk exocentric compound, karena jargon itu tidak memiliki inti kata (head) untuk mengetahui makna yang ada. Super shell merupakan sneakers Adidas hasil kerja sama (collaboration) dengan Pharell Wiliam yaitu jenis sneakers dengan gambar yang ada pada bagian shelltoe, yaitu bagian sneakers Adidas yang menyerupai kerang dan menutupi jari kaki. Berdasarkan kategorinya, jargon super shell merupakan compound nomina karena terbentuk dari kata super yang berkategori adjektiva dan kata shell yang berkategori nomina.

\section{Data 21: Super Color}

Pengkajian secara morfologis pada jargon super color menunjukkan bagian dari proses morfologis yang disebut compounding atau dalam bahasa Indonesia disebut kata majemuk. Proses compounding pada jargon super color dibentuk dengan cara menggabungkan dua morfem bebas, yaitu morfem super dan morfem color. Jargon super color merupakan kata majemuk yang ditulis dengan bentuk open form (bentuk terbuka) karena jargon super color ditulis sebagai kata terpisah. Jargon super color merupakan bentuk dari kata majemuk endocentric compound, karena jargon itu memiliki satu inti kata (head) untuk mengetahui makna yang ada. Adapun inti kata itu terletak pada kata color, karena super color merupakan sneakers Adidas hasil collaboration dengan Pharell Wiliam yaitu jenis sneakers dengan model yang sama namun dirilis dengan lima puluh warna yang berbeda. Berdasarkan kategorinya, jargon super color merupakan compound nomina karena terbentuk dari morfem super yang berkategori adjektiva dan morfem color yang berkategori nomina.

\section{Data 22: Super Court}

Pengkajian secara morfologis pada jargon super court menunjukkan bagian dari proses morfologis yang disebut compounding atau dalam bahasa Indonesia disebut kata majemuk. Proses compounding pada jargon super court dibentuk dengan cara menggabungkan dua morfem bebas, yaitu morfem super dan morfem court. Jargon super court merupakan kata majemuk yang ditulis dengan bentuk open form (bentuk terbuka) karena jargon super court ditulis sebagai kata terpisah. Jargon super court merupakan bentuk dari kata majemuk exocentric compound, karena jargon itu tidak memiliki inti kata (head) untuk mengetahui makna yang ada. Super court merupakan jenis sneakers Reebok yang digunakan untuk olah raga tennis di dalam ruangan. Berdasarkan kategorinya, jargon super court merupakan compound nomina karena terbentuk dari morfem super yang berka-tegori adjektiva dan morfem court yang berkategori nomina.

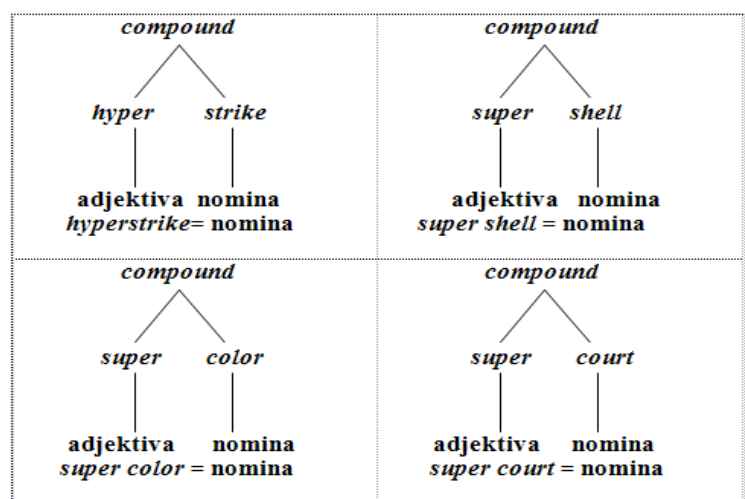

Gambar 6. proses pembentukan jargon compounding hyeperstrike, super shell, super color, dan super court

\section{SIMPULAN}

Hasil dari penelitian ini dapat disimpulkan bahwa compounding dalam jargon sneakers berbahasa Inggris dalam komunitas sneakerhead di Bandung berdasarkan bentuknya yang terbagi menjadi bentuk tulisan dan bentuk kata majemuk didapati bentuk tulisan close form (bentuk tertutup) yang ditulis sebagai kata tunggal dan open form (bentuk terbuka) yang ditulis sebagai kata terpisah, kemudian, bentuk kata majemuk dalam penelitian ini didapati dua yaitu endocentric compound, yaitu compounding yang maknanya dapat di tentukan dari salah satu inti kata compounding itu, dan exocentric compound, yaitu compounding yang benar-benar memiliki makna baru dan tidak mempertahankan makna asal atau tidak memiliki inti kata untuk menentukan makna itu. Berdasarkan kategorinya didapati kategori compound nomina yang dapat dibedakan menjadi tiga bagian yaitu compound nomina (nomina+nomina), compound nomina (nomina+ verba), dan compound nomina (nomina+adjektiva / adjektiva + nomina). 


\section{UCAPAN TERIMA KASIH}

Penulis mengucapkan terima kasih yang sebesarbesarnya kepada mitra bersari yang telah melakukan peer reviewer terhadap artikel ini.

\section{DAFTAR PUSTAKA}

Archibald, W.O. (2016). Contemporary Linguistic Analysis An Intoduction. Toronto: Library and Archives Canada Cataloguing in Publication.

Booij, G. (2005). The Grammar of Word. United States: Oxford University Press..

Cahyanti, R.D. (2016). Compound Words Used in Stephanie Meyer's Twilight. Journal on English as Foreign Language , 6, (2), 61-66.

Firdaus, W. (2011). Kata-kata Serapan Aceh dari Bahasa Arab: Analisis Morfosemantis. Sosiohumaniora, 13, (2), 223-224.

Garing, J. (2017). Penggunaan Jargon oleh Komunitas Waria di Jejaring Sosial Facebook. Ranah Jurnal Kajian Bahasa, 6, (1), 1-29.
Giyatmi, R. W. (2018). Blending Sebuah Alternatif dalam Penamaan Makanan dan Minuman Ringan. Addabiyat, 2, (2), 156-180.

Lieber, R. (2007). Introducing to Morphology. United States: Cambridge University Press.

Longman. (2000). Longman Dictionary of American English. England: Longman Group UK Ltd.

Napitupulu, F. (2016). Comparative Study of Compound Words in English and Indonesian. The Episteme Journal of Linguistic and Literature, 3, (1), 1-7.

Plag, I. (2002). Word Formation In English . New York: Cambridge University Press .

Pratiwi, D. W. (2015). Penggunaan Jargon oleh Narapidana di Lapas Wanita Kelas IIA Medan. Jurnal Sasindo, 6, (2), 1-12.

Smith, N. (2018). Kicks The Great American Story of Sneakers. New York : Crown Publishing.

Sudaryanto. (2015). Metode dan Aneka Teknik Analisis Bahasa. Yogyakarta: Sanata Dharma University Press.

Yule, G. (2016). The Study of Language. United States: Cambridge University Press. 